\title{
Egg Structures of Anopheles fluminensis and Anopheles shannoni
}

\section{LP Lounibos/ ${ }^{+}$, D Duzak, JR Linley ${ }^{\dagger}$, R Lourenço-de-Oliveira*}

\begin{abstract}
Florida Medical Entomology Laboratory, University of Florida, $2009^{\text {th }}$ St. SE, Vero Beach, Florida 32962 , U.S.A. *Departamento de Entomologia, Instituto Oswaldo Cruz, Av. Brasil 4365, 21045-900 Rio de Janeiro, RJ, Brasil
\end{abstract}

Eggs of two species belonging to the Arribalzagia Series of the Laticorn Section of Anopheles (Anopheles) collected in Brazil are described from scanning electron micrographs. The An. fluminensis egg is long with shallow floats displaced far dorsally. The narrow deck region is overlain by a frill modified into prominent ridges that are nearly continuous to both ends of the egg. Slightly opened decks at both poles contain an average of four lobed tubercles. Polygonal, plastron-type chorionic cells cover the lateral and dorsal surfaces. The egg of An. shannoni is unique in possessing 22-27 fingerlike filaments that project with regular spacing from each of its massive floats. These filaments and their bases are highly perforated and are believed to trap air and support flotation of the egg with the dorsal surface up, contrary to the usual orientation for anophelines. The eggs are compared with those of related species bearing similar structures, notably An. fluminensis with An. mediopunctatus s.s and An. shannoni with An. peryassui.

Key words: Anopheles - Brazil - eggs - malaria - morphology - scanning electron microscopy

Species identifications of malaria vectors by morphological characters of adults are problematic and often unsatisfactory. The first evidence of an anopheline species complex, whose members were indistinguishable in the adult stage, came from comparative examinations of eggs of Anopheles maculipennis s.l. Meigen from southern Europe (Falleroni 1926, Hackett \& Missiroli 1935). The identification of cryptic species by egg structures led to a surge of interest among entomologists and malariologists in the systematics potential of this neglected life stage (e.g. Galvão 1938, Rozeboom 1938, 1942, Kumm 1941). A comprehensive study based on over 28,000 ovipositions by 30 species led to an illustrated key to the eggs of Brazilian Anopheles (Causey et al. 1944). Limitations to this research included multiple egg morphs within some species and the low resolution of the light microscope for observing the intricate details of egg structures.

\footnotetext{
This work was supported by grants from the National Institutes of Health (AI-31034) of the U.S.A. and CNPq, PAPES/FIOCRUZ and FNS of Brazil, and is University of Florida IFAS Journal Series No. R-05309.

${ }^{+}$Corresponding author. Fax: +561-778.7205. E-mail: lpl@icon.vero.ufl.edu

Deceased

Received 13 August 1996

Accepted 10 October 1996
}

For many subsequent years anopheline eggs received scant attention until Hinton (1968) recognized the potential of the scanning electron microscope (SEM) for visualizing egg microstructures and, by extension, new morphological characters for species recognition. However, only in the present decade has the SEM been applied extensively to eggs of New World Anopheles for describing structural details (e.g. Linley \& Lounibos 1993, 1994), intraspecific variation (Rodriguez et al. 1992), geographic differentiation (Linley et al. 1996), and for separating members of species complexes (Linley et al. 1993) or separate species mistakenly synonymized (Lounibos et al. manuscript in preparation).

The present study describes the ultrastructure of eggs of two anopheline species that had previously been known only at the light microscope level. Anopheles (Anopheles) fluminensis was originally described by Root (1927) from the State of Rio de Janeiro, and its egg was first depicted by Causey et al. (1944) from Amazonian collections of this species. Although it has not been regarded as a vector in malarious regions of Brazil (Cerqueira 1961), mosquitoes identified as $A n$. sp. near fluminensis were incriminated as vectors of human malaria in eastern Peru (Hayes et al. 1987). The first illustration of the egg of An. shannoni Davis, at the time undescribed, was by Bonne and Bonne-Wepster (1925) (as An. mediopunctatus [Theobald]). The highly modified egg of this species was first described by Causey et al. (1944) 
from collections in the State of Pará, Brazil, the type locality of An. shannoni (Davis 1931). Anopheles shannoni has not been suspected as a vector of human malaria (Deane et al. 1948, Cerqueira 1961), in part because it prefers to bite in the canopy of forested regions (Deane et al. 1953). However, such acrodendrophilic host-seeking behavior makes An. shannoni a possible maintenance vector of simian malaria where this mosquito species and monkeys co-occur in the Amazon region (Lourenço-de-Oliveira \& Luz 1996).

Both An. fluminensis and An. shannoni belong to the Arribalzagia Series of the Laticorn Section (Reid \& Knight 1961) of the subgenus Anopheles. Wilkerson and Peyton (1990) inferred a monophyletic origin of the Arribalzagia Series based upon wingspot characters. Since eggs of several other species of this Series have been described recently using the SEM (Linley \& Lounibos 1994, Linley \& Milstrey 1995, Lounibos et al. in preparation), we infer in this paper possible species affinities based on egg structures.

\section{MATERIALS AND METHODS}

Female An. fluminensis were collected in January 1995 from human bait at Picinguaba, State of

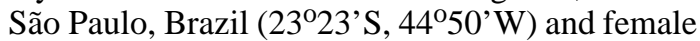
An. shannoni were collected by the same method in July 1994 at Samuel Ecological Station, State of Rondônia, Brazil ( $\left(9^{\circ} 07^{\prime}\right.$ 'S, 63ำ $\left.16^{\prime} \mathrm{W}\right)$. Blood-fed females, identified with the keys of Consoli and Lourenço-de-Oliveira (1994), were isolated individually in small vials with damp filter paper for oviposition. Laid eggs were allowed $24 \mathrm{hr}$ at $26^{\circ} \mathrm{C}$ to embryonate before preservation in alcoholic Bouin's fixative. A few eggs of An. shannoni were immersed in water prior to fixation in order to allow float filaments to unfurl, as accomplished previously for An. peryassui Dyar and Knab (Linley \& Lounibos 1994). In preparation for microscopy, eggs were removed from fixative, washed twice in $80 \%$ ethanol, then dehydrated in an ethanol series of $5 \%$ concentration increments. After critical point drying, eggs were mounted on stubs coated with sticky tape, sputter-coated with gold/palladium, and examined in an Hitachi S-510 SEM.

Electron micrographs of eggs were either scanned and rendered as computer images for measurements with SigmaScan software (Jandel Scientific, San Rafael, CA, U.S.A.), or measurements were made with a digitizing tablet and tabulated with the same software. Except where otherwise noted, measurements of An. fluminensis were made on 10-12 eggs laid by three females, and of $A n$. shannoni on 4-6 eggs from one female. Mean values in the text are followed by $\pm 1 \mathrm{SE}$. The descriptive terminology follows that of Harbach and
Knight (1980) except for "plastron" which conforms to the usage of Hinton (1968) to describe the network of structures that form a physical gill beneath the water line of anopheline eggs. Voucher specimens of adult females have been deposited in the Department of Entomology, FIOCRUZ.

\section{DESCRIPTIONS}

\section{Anopheles fluminensis (Figs 1-4)}

Size: egg length 515.4-546.2 $\mu \mathrm{m}$ (mean 530.8 $\pm 3.3 \mu \mathrm{m}, \mathrm{n}=10$ ), width $180.8-203.8 \mu \mathrm{m}$ (mean $187.7 \pm 2.2 \mu \mathrm{m}, \mathrm{n}=10)$, length/width ratio 2.68 2.91 (mean $2.83 \pm .03, \mathrm{n}=10$ ). Color: black. Overall appearance: long and wide across floats, especially anteriorly, but tapering abruptly where floats terminate before anterior and posterior ends (Fig. 1a); egg boat-shaped in lateral view, dorsal surface concave but ventral surface flat (Fig. 1b); floats shallow and displaced unusually far dorsally (Fig. 1b).

Ventral (upper) surface: deck usually hidden by overlapping frills which form ventral ridges for length of the egg except for anterior and posterior poles (Figs 2a,d). When visible, deck deeply recessed between ridges which are deeply grooved in both ventral and lateral views (Figs 4a,d). Both anterior and posterior decks open, containing 3-5 mushroom-like, lobed tubercles (mean anterior 4.0 +0.2 , mean posterior $3.8 \pm 0.2, \mathrm{n}=12$ ) (Figs $2 \mathrm{c}, \mathrm{f}$ ). Smaller tubercles of both anterior and posterior decks irregular, some star-shaped, and domed with buttressed walls (Figs 3a,c). Tubercles of middle deck, exposed infrequently because of ridge overlap, less densely packed and shorter, some marooned on chorionic islets (Fig. 3b).

Ventral plastron flanking ridges and deck, wide and occupied by hexagonal chorionic cells with boundaries distinguished by raised tubercles (Figs $1 \mathrm{~b}, 4 \mathrm{~b})$. Cells longer than wide, these dimensions consistent for length of egg (mean cell length 35.6 $\pm 0.5 \mu \mathrm{m}$, mean width $16.0 \pm 0.6 \mu \mathrm{m}, \mathrm{n}=20)$. Interior of chorionic cells with rounded, tightly packed tubercles, less raised than perimeter tubercles (Fig. $4 c)$.

Anterior end, micropyle: anterior end blunt, frill extending around lobed tubercles but reduced between tubercles and micropyle (Fig. 2b). Chorionic cells continuous with lateral hexagonal ones, more compressed and irregularly shaped anteriorly (Fig. 2b). Micropylar disc divided into 6-7 sectors (mean $6.8 \pm 0.1, \mathrm{n}=10$ ) by short rays from collar (Fig. 2g). Micropylar collar generally smooth but with shallow pits; disc surface rugose. Micropylar orifice set in low mound (Fig. 2g).

Posterior end: blunt in end-on view (Fig. 2e), otherwise similar in conformation to ventral view 

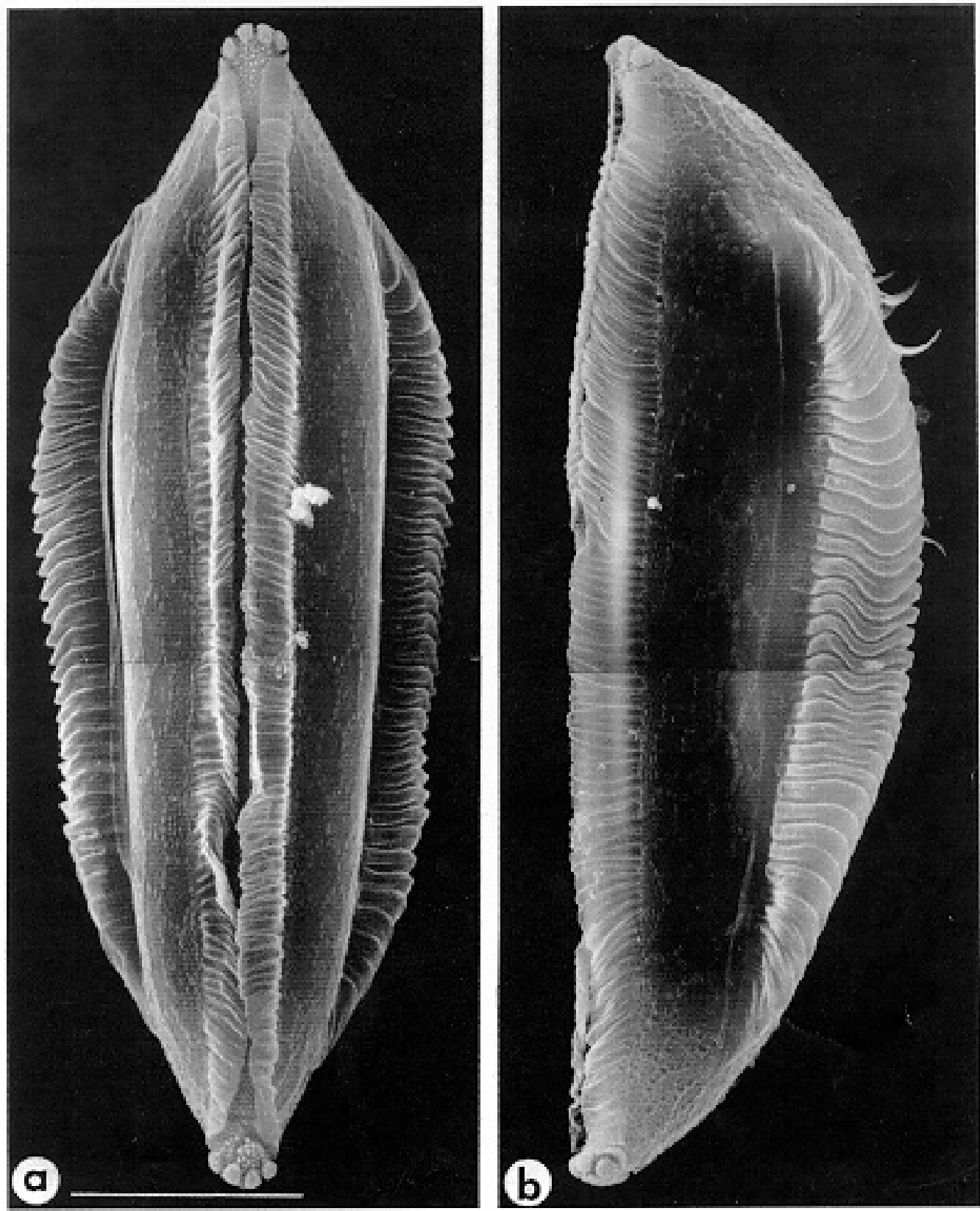

Fig. 1: Anopheles fluminensis - a: entire egg, ventral view, anterior end at top. b: entire egg, lateral view, ventral surface at left, anterior end at top. Scale $=100 \mu \mathrm{m}$.

of anterior end (Figs 2a cf. 2d).

Dorsal (lower) and lateral surfaces: outer chorionic cells of dorsal plastron tending to form polygons, although some with rounded borders (Fig. 3e), length 24.7-34.7 $\mu$ m (mean $27.8 \pm 1.2$ $\mu \mathrm{m}, \mathrm{n}=10$ ), width 16.9-20.4 $\mu \mathrm{m}$ (mean $17.1 \pm 0.7$ $\mu \mathrm{m}, \mathrm{n}=10)$. Interior of cells with tightly packed tubercles like smooth cobblestone pavement (Fig. 3f). Exochorion continuous except for infrequent perforations between tubercles (Fig. 3f). Floats 
224 Eggs of Brazilian Anophelines - LP Lounibos et al.
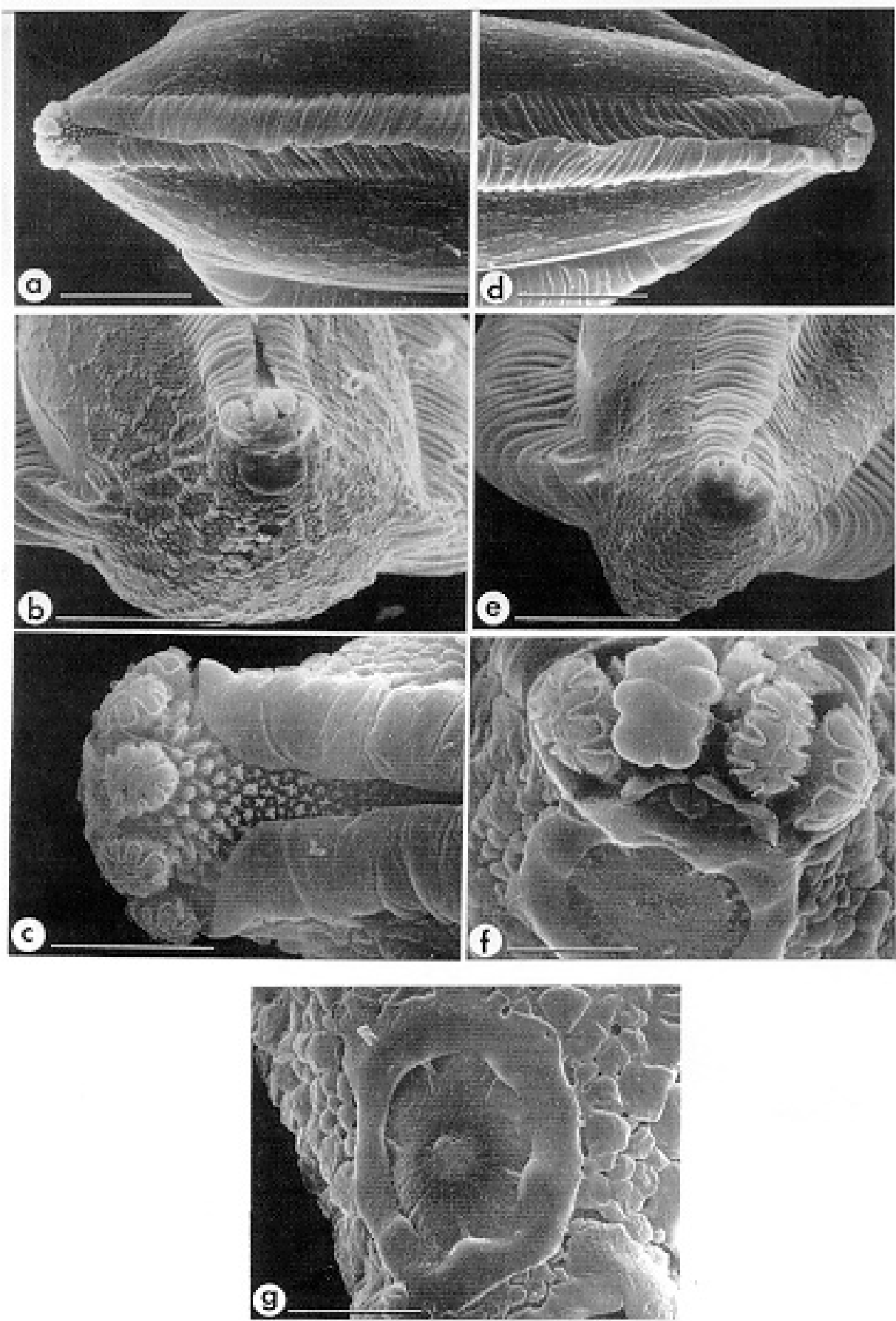

Fig. 2: Anopheles fluminensis - a: anterior end, ventral surface. b: anterior end, end-on view. c: detail of lobed and immediately adjacent deck tubercles, anterior end. d: posterior end, ventral surface. e: posterior end, end-on view. f: detail of lobed tubercles, posterior end-on view. g: detail of micropylar apparatus. Scale $=50 \mu \mathrm{m}(\mathrm{a}, \mathrm{b}, \mathrm{d}, \mathrm{e}),=20 \mu \mathrm{m}(\mathrm{c}),=10 \mu \mathrm{m}(\mathrm{f}, \mathrm{g})$. 

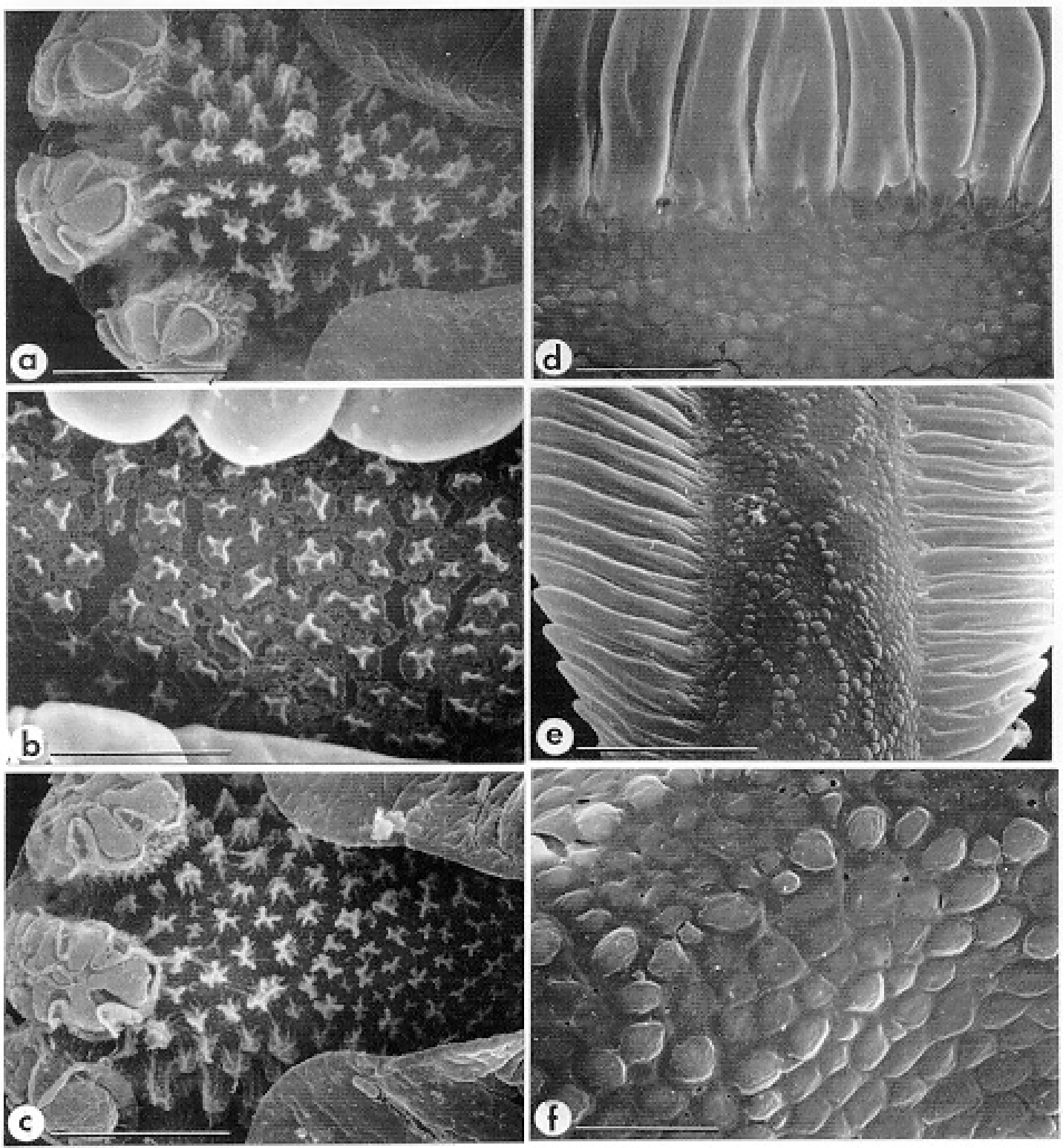

Fig. 3: Anopheles fluminensis - a: detail anterior deck tubercles. b: detail middle deck tubercles. c: detail posterior deck tubercles. d: ventral margin of float at junction with dorsal plastron. e: dorsal plastron, middle of egg. f: detail of chorionic cells, dorsal plastron. Scale $=50 \mu \mathrm{m}(\mathrm{e}),=20 \mu \mathrm{m}(\mathrm{d}),=10 \mu \mathrm{m}(\mathrm{a}, \mathrm{b}, \mathrm{c}, \mathrm{f})$.

deeply grooved to margin with dorsal surface (Fig. $3 d$ ), the grooved sutures undulating near egg midline in lateral view (Fig. 1b). Boundary between float and lateral chorionic cells separated by a narrow strip of tiny, densely packed tubercles (Fig. 4e); high magnification reveals these tubercles to be of varying sizes with smooth domes and buttressed roots, some with fine projections from roots (Fig. 4f). Lateral chorionic cells similar in detail to dorsal counterparts in polygonal shape, boundaries with smooth, raised tubercles, cobblestone-like interior and occasional perforations (Figs $4 \mathrm{~b}-\mathrm{d}$ ).

\section{Anopheles shannoni (Figs 5-8)}

Size: egg length 450.9-493.8 $\mu \mathrm{m}$ (mean 471.8 $6.9 \mu \mathrm{m}, \mathrm{n}=6$ ), width $167.1-189.7 \mu \mathrm{m}$ (mean $177.7 \pm$ $3.0 \mu \mathrm{m}, \mathrm{n}=6$ ), length/width ratio 2.39-2.85 (mean $2.66 \pm 0.07, \mathrm{n}=6)$. Color: black. Shape, overall appearance: egg boat-shaped in lateral view, curved in both dorsal and ventral surfaces (Fig. 5c), widest 

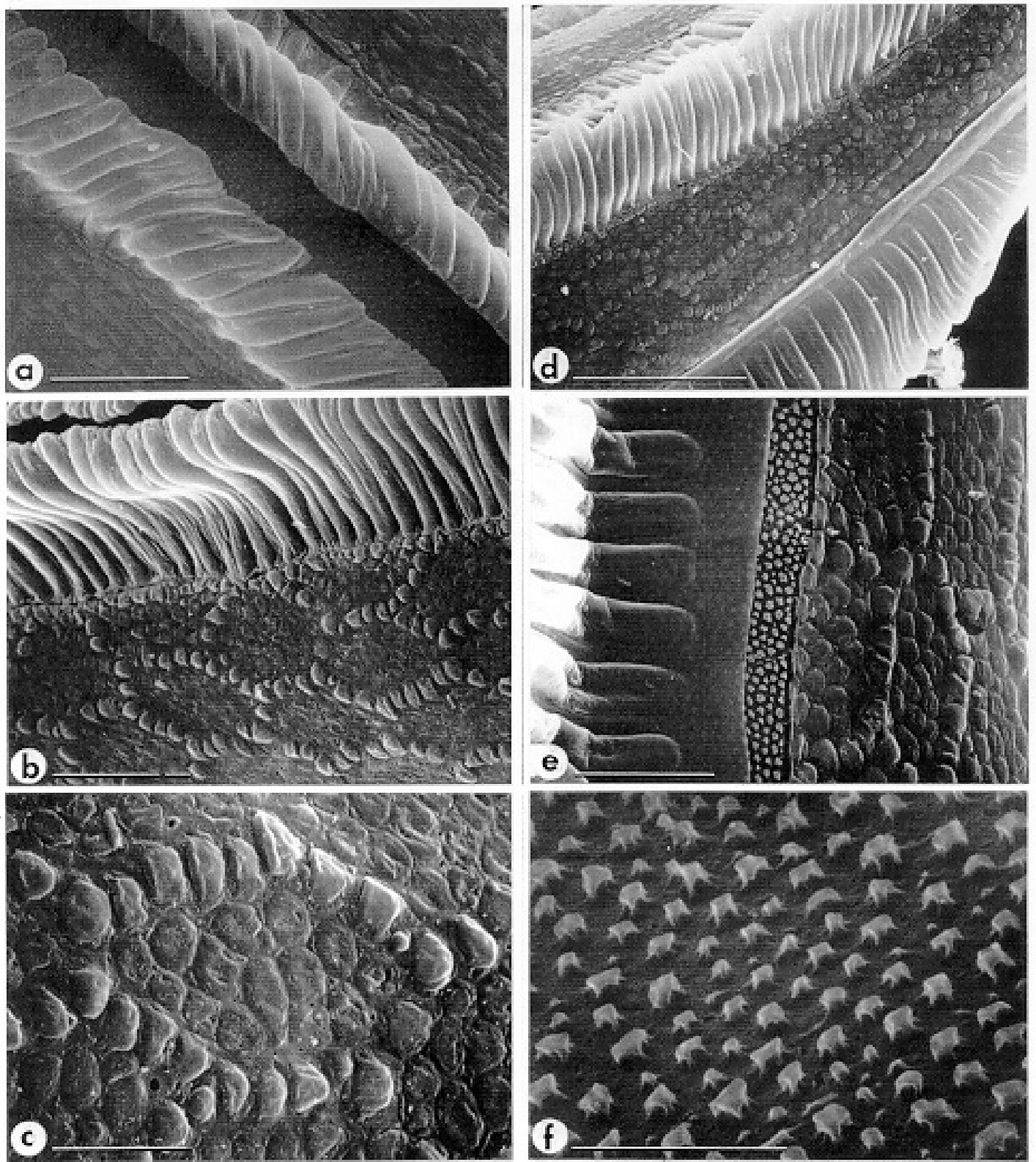

Fig. 4: Anopheles fluminensis - a: ridge, ventral view. b: ridge and chorionic cells, lateral view. c: detail of chorionic cells, lateral plastron. d: lateral area between ridge and float margins. e: detail of lateral cells and float margin. f: extreme detail of tubercles between float margin and chorionic cells. Scale $=50 \mu \mathrm{m}(\mathrm{d}),=20 \mu \mathrm{m}(\mathrm{a}, \mathrm{b}, \mathrm{e}),=10 \mu \mathrm{m}(\mathrm{c}),=5 \mu \mathrm{m}$ (f).

anteriorly at inception of floats, tapering slightly posteriorly (Fig. 5a). Anterior end blunt, posterior end slightly more conical (Fig. 5b). Deck broad and exposed, surrounded by ventral margins of floats except for narrow passages to anterior and posterior poles (Fig. 5b). Floats elaborately developed and highly concave, positioned closer to dorsal than ventral surface (Fig. 5c). Regularly spaced, filamentous projections (range 22-27, mean $25.4 \pm 0.4, \mathrm{n}=8$ ) extend from dorsum of float throughout its length, filaments longer and projecting more ventrally near anterior and posterior poles (Figs 5c, 8b,c). In speci- 

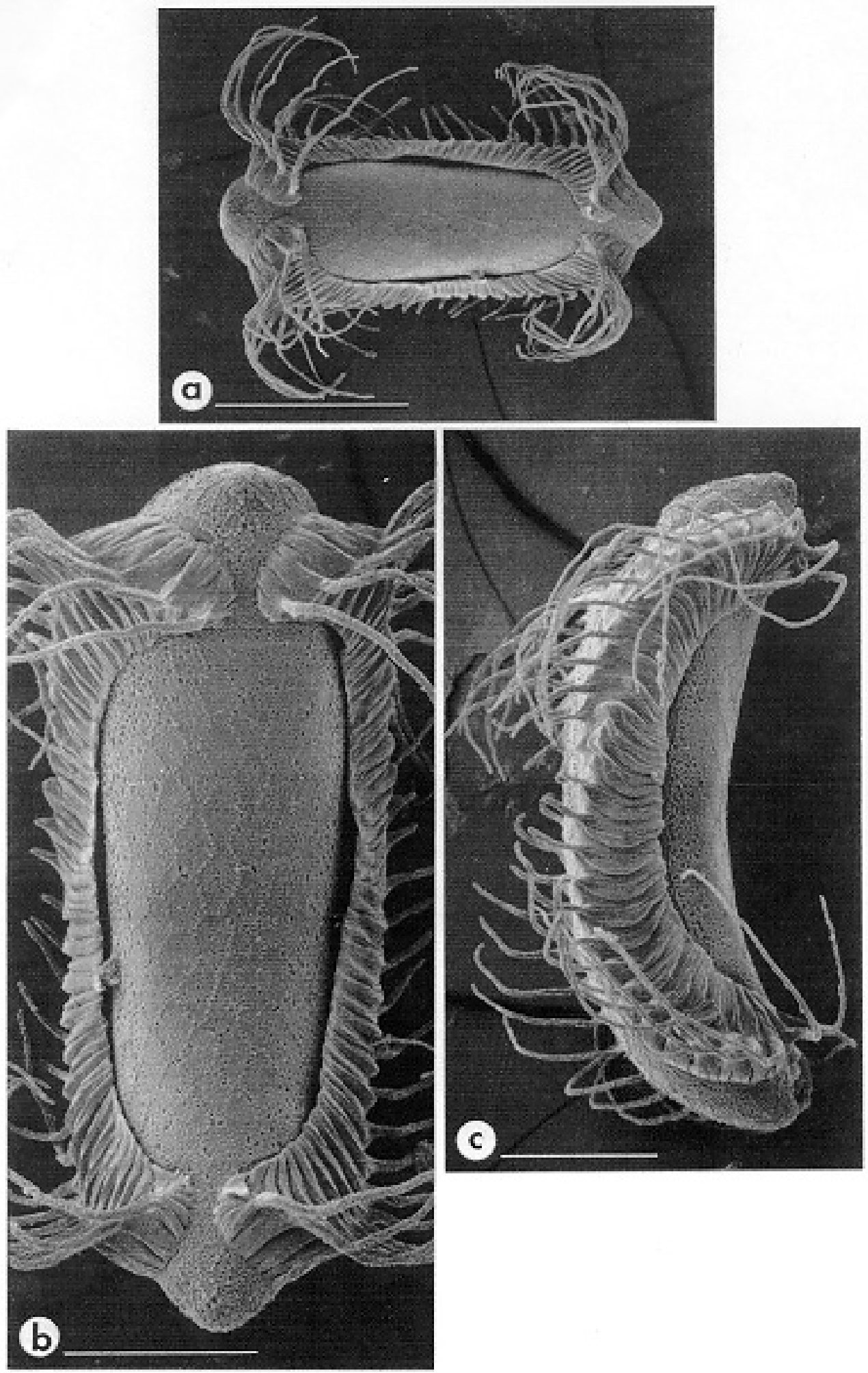

Fig. 5: Anopheles shannoni - a: entire egg, ventral view, showing expanded filaments, anterior end at left. b: entire egg, expanded ventral view, anterior end at top. c: entire egg, lateral view, anterior end at top, ventral surface at right. Scale $=200 \mu \mathrm{m}$ (a), $=100 \mu \mathrm{m}(\mathrm{b}, \mathrm{c})$. 

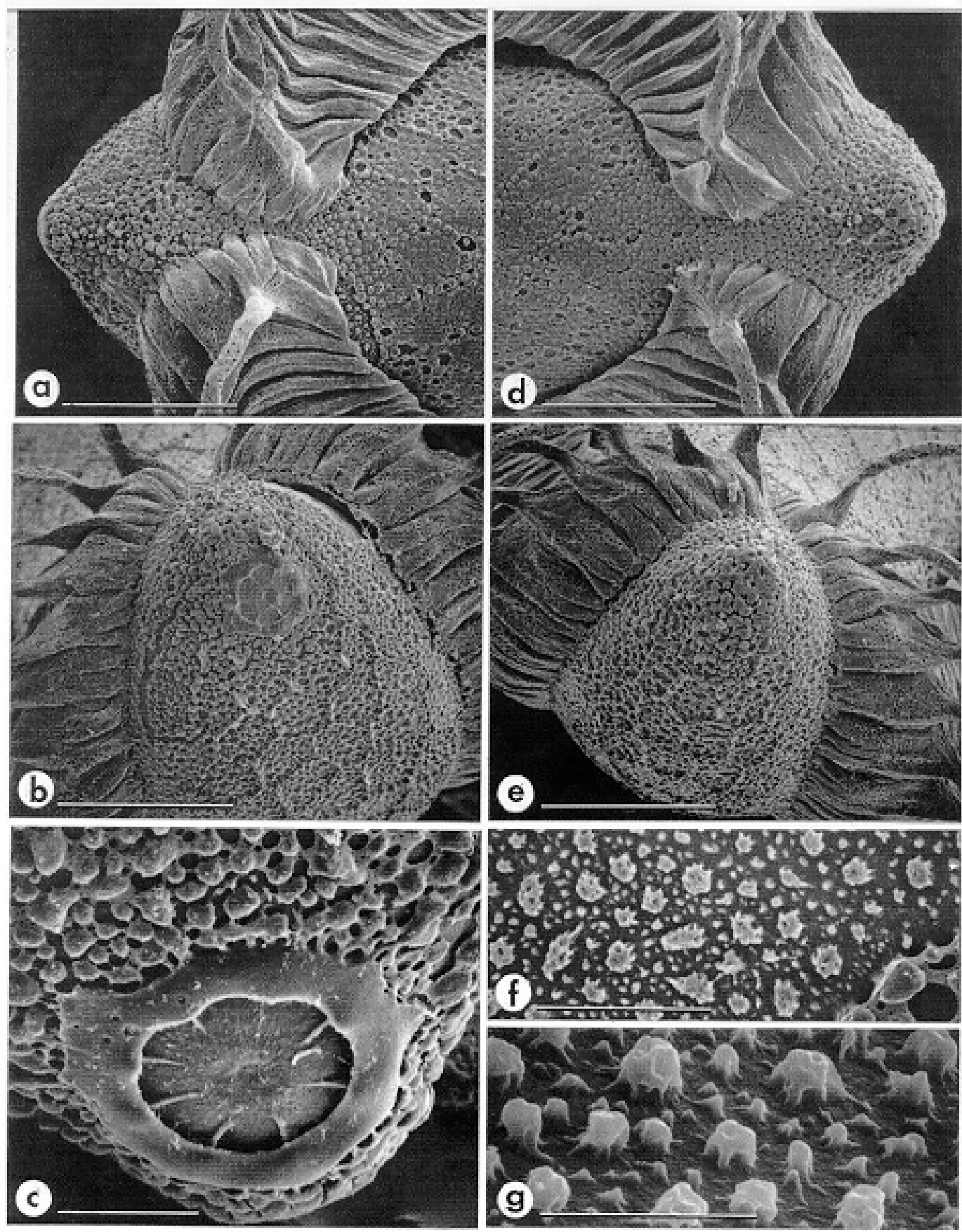

Fig. 6: Anopheles shannoni - a: anterior end, ventral surface. b: anterior end, end-on view. c: detail of micropylar apparatus. d: posterior end, ventral surface. e: posterior end, end-on view. f: detail, tubercles under float. g: extreme detail, tubercles under float. Scale $=50 \mu \mathrm{m}(\mathrm{a}, \mathrm{b}, \mathrm{d}, \mathrm{e}),=10 \mu \mathrm{m}(\mathrm{c}, \mathrm{f}),=5 \mu \mathrm{m}(\mathrm{g})$.

mens fixed before exposure to water, filaments appressed flat against egg (Fig. 8a).

Ventral surface: uniformly covered with polygonal (some rhomboidal, some hexagonal) plas- tron-type outer chorionic cells (Figs $5 \mathrm{~b}, 7 \mathrm{a}$ ), length 30.7-38.2 $\mu \mathrm{m}$ (mean $34.3 \pm 0.5 \mu \mathrm{m}, \mathrm{n}=21$ ), width 17.6-26.0 $\mu \mathrm{m}$ (mean $22.7 \pm 0.5 \mu \mathrm{m}, \mathrm{n}=21$ ), cell boundaries less distinct in lateral region where 

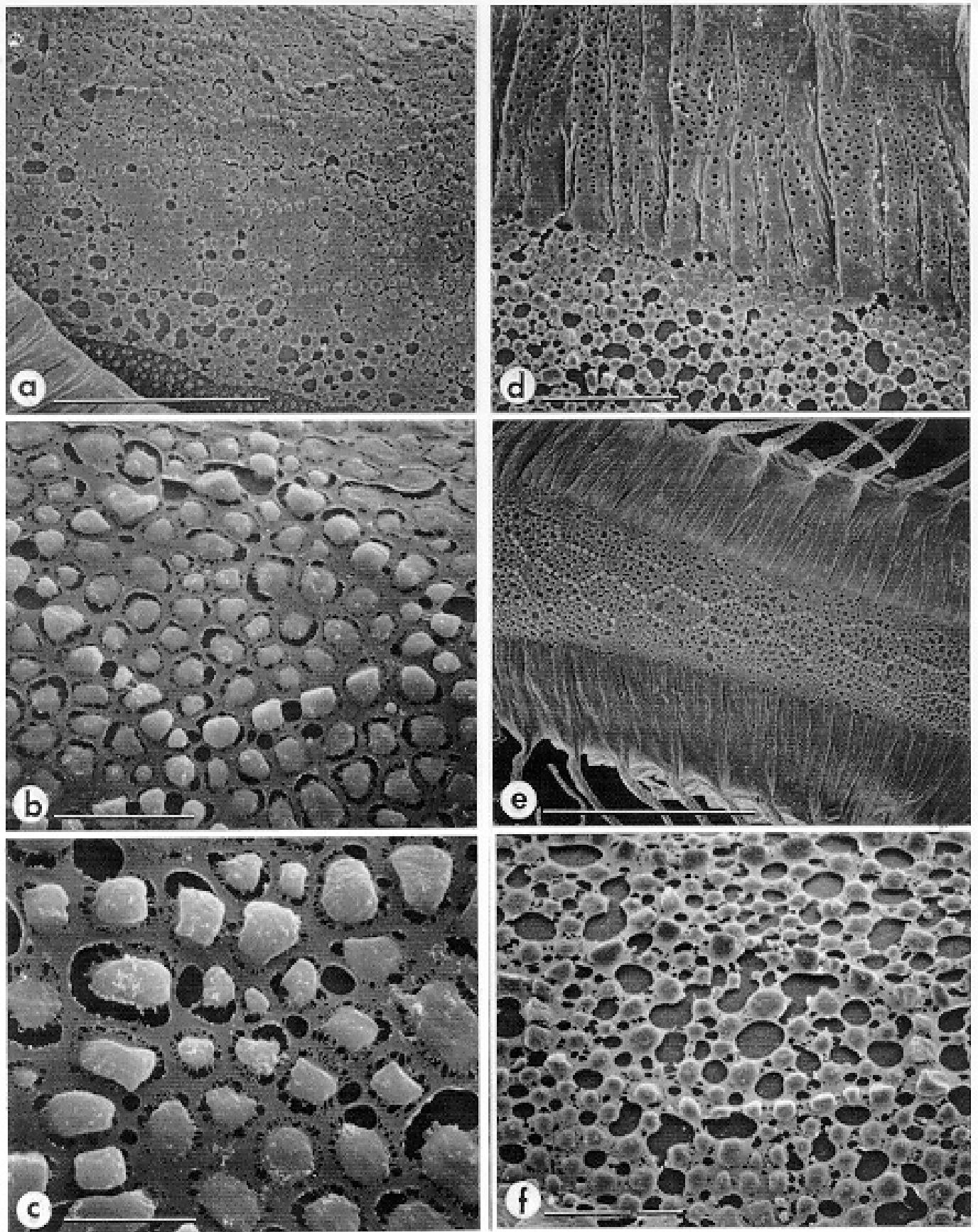

Fig. 7: Anopheles shannoni - a: ventral plastron, anterior of egg. b, chorionic cell, ventral plastron. c: cell detail, ventral plastron. d: dorsal surface and float margin. e: dorsal surface, middle of egg, showing plastron and float margins. f: chorionic cells, plastron of dorsal surface. Scale $=100 \mu \mathrm{m}(\mathrm{e}),=50 \mu \mathrm{m}(\mathrm{a}),=20 \mu \mathrm{m}(\mathrm{d}),=10 \mu \mathrm{m}(\mathrm{b}, \mathrm{f}),=5 \mu \mathrm{m}(\mathrm{c})$.

chorion layer more perforated (Figs 5c, 7a). Detail shows cell boundaries formed by smooth, raised tubercles, often surrounded by gaping, or a latticework of, perforations (Figs 7b,c); structure of within-cell tubercles similar to perimeter but less elevated (Fig. 7b).

Floats: massive, dominating entire lateral aspect of egg except for mid-ventral region and ends (Fig. 5c). Float surfaces perforated by pores occurring both on ribs and filaments (Figs 8d-f); pores 

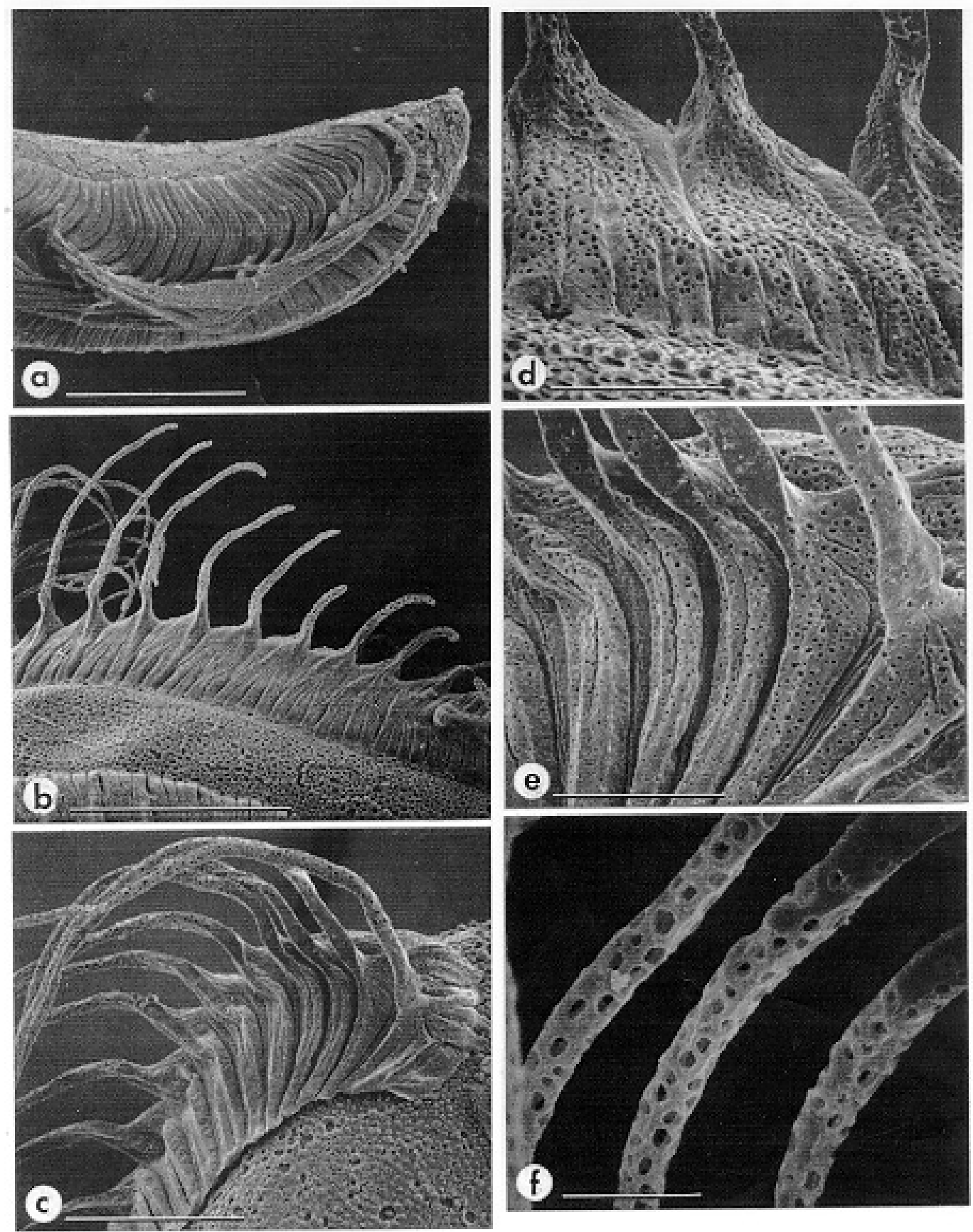

Fig. 8: Anopheles shannoni - a: lateral view of float with filaments unexpanded. b: dorsal view near middle of egg, filaments extended. c: ventral view of filament bases at anterior end. d: filament bases, dorsal view. e: detail of filament bases at anterior end. f: detail of pores in extended filaments. Scale $=100 \mu \mathrm{m}(\mathrm{a}, \mathrm{b}),=50 \mu \mathrm{m}(\mathrm{c}),=20 \mu \mathrm{m}(\mathrm{d}, \mathrm{e}),=10 \mu \mathrm{m}$ (f).

less frequent on ventral margins (Figs $5 \mathrm{~b}, 8 \mathrm{a}, \mathrm{c}$ ). Filaments originate from separate float segments of similar width (range 21.6-33.0 $\mu \mathrm{m}$, mean 26.5 $\pm 0.9 \mu \mathrm{m}, \mathrm{n}=16$ ) (Figs 8b,d). Filaments longer at either end of egg, where they arch dorsally (Figs $5 \mathrm{c}, 8 \mathrm{~b})$, becoming progressively shorter toward midline (Figs 5a, 8b). Filaments tubular, diameter 4.1-5.6 $\mu \mathrm{m}$ (mean $4.6 \pm 0.2 \mu \mathrm{m}, \mathrm{n}=10$ ), perfora- 
tions oval, length $0.9-1.9 \mu \mathrm{m}$ (mean $1.3 \pm 0.1 \mu \mathrm{m}$, $\mathrm{n}=20$ ), width 0.7-1.6 $\mu \mathrm{m}$ (mean $1.0 \pm 0.04 \mu \mathrm{m}$, $\mathrm{n}=20$ ), regularly distributed over filament surface (Fig. 8f). Chorion beneath float with densely packed tubercles of varying sizes (Fig. 6f), which are dome-shaped with buttressed walls under high magnification (Fig. 6g).

Anterior end, micropyle: anterior end somewhat conical, floats terminating in ventral surface before pole, left and right sides separated by narrow chorion strip (Fig. 6a). Micropylar apparatus located dorsally to an agglomeration of cauliflowerlike tubercles (Fig. 6b). Micropylar collar smooth, slightly scalloped on interior margin (Fig. 6c), radial arms extend from collar approximately halfway into disc area. Micropylar orifice recessed in low mound (Fig. 6c).

Posterior end: no obvious distinctions from anterior end in ventral view, floats terminating dorsomedially before pole (Fig. 6d). End-on view shows cauliflower-like tubercles clustered at pole and distinctive from those forming polygonal cells of dorsal chorion (Fig. 6e).

Dorsal surface: area covered by polygonal (mostly hexagonal) chorionic cells of length 30.3$35.9 \pm \mu \mathrm{m}$ (mean $33.1 \pm 0.6 \mu \mathrm{m}, \mathrm{n}=12)$, width 18.5 $23.4 \mu \mathrm{m}$ (mean 19.6-0.4 $\mu \mathrm{m}, \mathrm{n}=12$ ), area occupied by cells narrow in middle of egg owing to dorsal position of floats (Fig. 7e). Interior of cells composed of rounded, slightly raised tubercles with many round or ovoid pores exposing lower chorion layer (Fig. 7f). No change in surface structure near margin with float (Fig. 7d).

\section{DISCUSSION}

The light microscopic descriptions by Causey et al. (1944) of eggs of An. fluminensis and An. shannoni are accurate insofar as their limited resolution allows. These authors depict the frill of $A n$. fluminensis "surrounding (a) wide, elliptical black area", which indicates that the deck of their specimens was more exposed than those of the current study. For An. shannoni drawn by Causey et al. (1944), the segments of floats near the midline do not give rise to filamentous projections, and the floats are positioned more ventrally than in our specimens.

The egg of An. fluminensis, distinctive for its ventral ridges and dorsally positioned floats, is not likely to be confused with that of any other described anopheline species. Among related species examined with the SEM, the egg of $A n$. mediopunctatus s.s. most resembles that of $A n$. fluminensis. However, the central deck of $A n$. mediopunctatus s.s. is more exposed than in An. fluminensis and its dorsal ridges are coalesced into whorls (Lounibos et al. in preparation). Interestingly, the type locality of both these species is southeastern Brazil. Examinations of eggs of the malaria vector $A n$. sp. near fluminensis from eastern Peru would be valuable for establishing its relationship to An. fluminensis from the type locality.

The filamentous projections of the floats of $A n$. shannoni invite comparisons to the homologous extensions of the floats of An. peryassui (Linley \& Lounibos 1994), which species is also placed in the Arribalzagia Series. Filaments of both species are compressed laterally until the newly laid egg touches water and are highly perforated, presumably to entrap air and assist flotation.

However, float filaments differ between $A n$. shannoni and An. peryassui in many structural details. In the former species, these extensions project regularly from the complete length of massive floats. In An. peryassui, filaments are confined to the anterior and posterior ends, and the floats of this related species are much more slender than those of An. shannoni. Further, perforations on the margins and bases of the floats are larger and more abundant in An. peryassui. Additional features distinguish the eggs of the two species: An. shannoni eggs have no frill or crown, which occur at both ends of the An. peryassui egg [although Causey et al. (1944) show some An. peryassui without frills or crowns]; the mean egg length/width ratio is 4.0 for An. peryassui and 2.7 for $A n$. shannoni; the ventral surface is highly concave in $A n$. shannoni but only slightly concave in $A n$. peryassui.

Observations on An. peryassui eggs laid in water led to the conclusion that the natural flotation position of this species is dorsal side up (Linley $\&$ Lounibos 1994). In view of the many structural similarities of eggs of the two species, we anticipate that An. shannoni eggs also float in this position, which is unique to these species of Anopheles. The ventral deck of both species, which would be submerged, is covered with porous, plastronlike chorionic cells, usually typical of dorsal surfaces, which entrap air for respiration. The larval habitat of An. shannoni is reported to be filled with leaves, branches and tree trunks (Deane et al. 1948). As conjectured for eggs of An. peryassui which also occur in detritus-laden habitats, the filaments of An. shannoni eggs may support their flotation by attachment to buoyant debris.

\section{ACKNOWLEDGEMENTS}

To D Couto Lima, J Conn and M Motta for their help in field collections; to J Conn and R Wilkerson for comments on a draft of this manuscript. 


\section{REFERENCES}

Bonne C, Bonne-Wepster J 1925. The Mosquitoes of Surinam. Med Kolon Inst Amst, Trop Hyg No. 13, $558 \mathrm{pp}$.

Causey OR, Deane LM, Deane MP 1944. An illustrated key to the eggs of thirty species of Brazilian anophelines with several new descriptions. Am J Hyg 39: 1-7.

Cerqueira NL 1961. Distribuição geográfica dos mosquitos da Amazônia. Rev Bras Ent 10: 111-168.

Consoli RAGB, Lourenço-de-Oliveira R 1994. Principais Mosquitos de Importância Sanitária no Brasil. Editora FIOCRUZ, Rio de Janeiro, 225 pp.

Davis NC 1931. A new anopheline mosquito from Pará, Brazil. Am J Hyg 13: 345-348.

Deane LM, Causey OR, Deane MP 1948. Notas sôbre a distribuição e a Biologia dos Anofelinos das regiões Nordestina e Amazônica do Brasil. Rev Serv Esp Saú Púb 1: 827-965.

Deane LM, Damasceno RG, Arouck R 1953. Distribuição vertical de mosquitos em uma floresta dos arredores de Belém, Pará. Fol Clin Biol 20: 101110.

Falleroni D 1926. Fauna anofelica italiana e suo "habitat" (paludi, risaie, canali). Metodi di lotta contra la malaria. Riv Malariol 5: 553-593.

Galvão ALA 1938. Observações sôbre algumas espécies do subgênero Nyssorhynchus, com especial referência à morfologia dos ovos. Rev Biol Hyg 9: 51-60.

Hackett LW, Missiroli A 1935. The varieties of Anopheles maculipennis and their relation to the distribution of malaria in Europe. Riv Malariol 14: 45-109.

Harbach RE, Knight KL 1980. Taxonomists' Glossary of Mosquito Anatomy. Plexus Publ. Inc., Marlton, New Jersey, xi + 413 pp.

Hayes J, Calderón G, Falcón R, Zambrano V 1987. Newly incriminated anopheline vectors of human malaria parasites in Junín Department, Peru. J Am Mosq Control Assoc 3: 418-422.

Hinton HE 1968. Observations on the biology and taxonomy of the eggs of Anopheles mosquitoes. Bull Ent Res 57: 495-508.

Kumm HW 1941. The eggs of some Costa Rica anophelines. Am J Trop Med 21: 91-98.
Linely JR, Lounibos LP 1993. The eggs of Anopheles (Nyssorhynchus) rangeli and Anopheles (Nyssorhynchus) dunhami (Diptera: Culicidae). Mosq Syst 25: 157-169.

Linley JR, Lounibos LP 1994. The remarkable egg of Anopheles peryassui (Diptera: Culicidae). Mosq Syst 26: $25-34$.

Linley JR, Milstrey EG 1995.The eggs of Anopheles (Anopheles) mattogrossensis and Chagasia fajardi (Diptera: Culicidae). Mosq Syst 27: 27-39.

Linley JR, Kaiser PE, Cockburn AF 1993. A description and morphometric study of the eggs of species of the Anopheles quadrimaculatus Complex (Diptera: Culicidae). Mosq Syst 25: 124-147.

Linley JR, Lounibos LP, Conn J, Duzak D, Nishimura N 1996. A description and morphometric comparison of eggs from eight geographic populations of the South American malaria vector Anopheles (Nyssorhynchus) nuneztovari (Diptera: Culicidae). J Am Mosq Control Assoc 12: 275-292.

Lourenço-de-Oliveira R, Luz SLB 1996. Simian malaria at two sites in the Brazilian Amazon - II. Vertical distribution and frequency of anopheline species inside and outside the forest. Mem Inst Oswaldo Cruz 91: 687-694.

Reid JA, Knight KL 1961. Classification within the subgenus Anopheles (Diptera, Culicidae). Ann Trop Med Parasit 55: 474-488.

Rodriguez MH, Chavez B, Orozco A, Loyola EG, Martinez-Palomo A 1992. Scanning electron microscopic observations of Anopheles albimanus (Diptera: Culicidae) eggs. J Med Ent 29: 400-406.

Root FM 1927. Studies on Brazilian mosquitoes. IV. Notes on some Brazilian species of Anopheles. Am J Hyg 7: 599-605.

Rozeboom LE 1938. The eggs of the Nyssorhynchus group of Anopheles (Culicidae) in Panama. Am J Hyg 27: 95-107.

Rozeboom LE 1942. Subspecific variations among neotropical Anopheles mosquitoes and their importance in the transmission of malaria. Am J Trop Med 22: $235-255$.

Wilkerson RC, Peyton EL 1990. Standardized nomenclature for the costal wing spots of the genus Anopheles and other spotted-wing mosquitoes (Diptera: Culicidae). J Med Ent 27: 207-224. 